
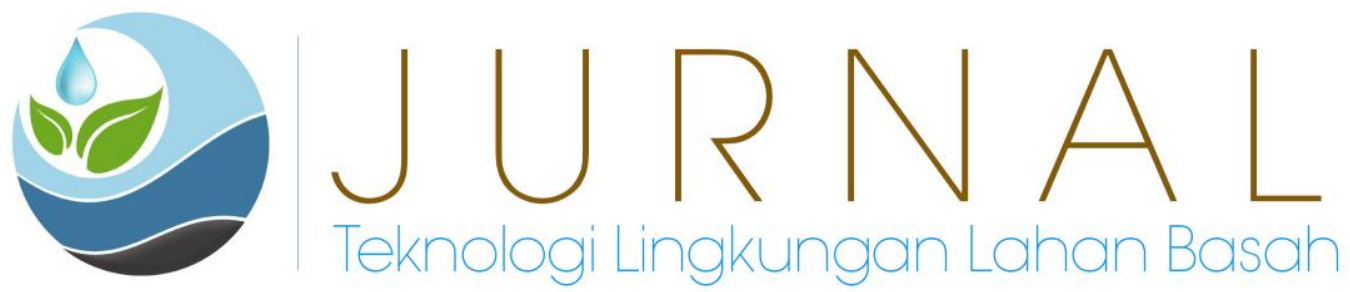

\title{
Pembuatan Pupuk Kompos Cair dari Air Buangan Industri Tahu
}

\author{
Indah Rakhmayani $^{1}$, Nabila Shafa Aulia ${ }^{1}$, Noviyanti ${ }^{1}$, Dian Rahayu Jati ${ }^{1}$, Isna Apriani ${ }^{1}$ \\ ${ }^{1}$ Jurusan Teknik Lingkungan, Universitas Tanjungpura \\ E-mail : indahrakhmayani@gmail.com,dianrahayujati1978@yahoo.com
}

\begin{abstract}
Cleaner production is an environmental processing strategy that is implemented on an ongoing basis to increase eco-efficiency in order to reduce risks to human health and the environment. The tofu industry in its production process produces waste, both solid and water. Disposal of waste directly to water bodies will damage the environment by creating unpleasant odors and the hot temperature of waste water which can affect the growth of aquatic biota. Tofu production produces $150 \mathrm{~L}$ of liquid waste from the soaking and filtering process. Meanwhile, $50 \mathrm{~kg}$ of solid waste is produced from milling soybeans. Solid waste will be used as animal feed and liquid waste will be processed into liquid compost.
\end{abstract}

Keywords: Tofu Production, Cleaner Production, Liquid Compos, Waste Minimization, Mass Balance.

\begin{abstract}
Abstrak
Produksi bersih merupakan strategi pengolahan lingkingan yang diterapkan secara berkelanjutan untuk meningkatkan ekofisiensi agar dapat mengurangi resiko terhadapat kesehatan manusia dan lingkungan. Industri tahu dalam proses produksinya menghasilkan limbah, baik padat maupun air. Pembuangan limbah langsung ke badan air akan merusak lingkungan dengan timbulnya bau tidak sedap dan suhu air limbah yang panas dapat mempengaruhi pertumbuhan biota air. Produksi tahu menghasilkan limbah cair sebanyak 150 L dari proses perendaman, dan penyaringan. Sedangkan limbah padat yang dihasilkan sebanyak $50 \mathrm{~kg}$ yang berasal dari penggilingan kacang kedelai. Limbah padat akan dijadikan pakan ternak dan limbah cair akan diolah menjadi pupuk kompos cair.
\end{abstract}

Kata Kunci : Industri Tahu, Produksi Bersih, Pupuk Kompos, Minimasi Limbah, Neraca Massa. 


\section{PENDAHULUAN}

Tahu merupakan makanan tradisional dengan bahan dasar kedelai. Tahu dibuat dengan proses penggumpalan (pengendapan) protein susu kedelai menggunakan cuka. Saat ini, industri tahu merupakan industri yang banyak dikenal masyarakat dikarenakan industri ini biasanya merupakan industri kecil rumahan yang terletak di sekitar pemukiman masyarakat. Industri tahu ini tentu akan menghasilkan buangan berupa limbah padat maupun cair yang diolah maupun langsung dibuang ke lingkungan atau badan air. Limbah padat industri tahu biasanya akan dijadikan pakan ternak dan limbah cair biasanya akan dibuang langsung ke lingkungan tanpa adanya proses penanganan terlebih dahulu. maka dari itu, tidak menutup kemungkinan akan terjadi kerusakan pada lingkungan.

Menurut Hartati (2003:8) beberapa kerusakan yang dapat terjadi jika limbah cair tahu langsung dibuang ke lingkungan yaitu, timbulnya bau yang tidak sedap, dan suhu limbah cair tahu yang panas dapat mempengaruhi proses pertumbuhan biota tertentu. Maka dari itu untuk mengurangi pencemaran yang terjadi akibat pembuangan limbah cair tahu, perlu adanya proses penanganan limbah cair tahu yang dilakukan terlebih dahulu. Salah satu upaya yang dapat dilakukan adalah dengan penerapan Produksi Bersih. Produksi Bersih merupakan strategi pengolahan lingkungan yang bersifat preventif, terpadu dan diterapkan secara berkelanjutan pada proses produksi dan jasa untuk meningkatkan ekoefisiensi sehingga mengurangi resiko terhadap kesehatan manusia dan lingkungan (Fauzi dan Indrasti, 2009).

Industri tahu merupakan salah satu industri yang membuang air limbahnya secara langsung ke lingkungan tanpa melalui proses terlebih dahulu. Pada prosesnya, industri ini menghabiskan $300 \mathrm{~kg}$ kedelai setiap harinya dan menghasilkan limbah padat dan cair. Limbah tersebut berupa sisa bahan baku yang tercecer, air sisa rendaman, dan abu sisa pembakaran. Sehingga perlu diadakan pengolahan lebih lanjut untuk limbah cair untuk mengurangi dampak dari pencemaran dan meningkatkan efisiensi. Penelitian ini dilakukan untuk mengurangi pencemaran limbah cair produksi tahu di industri rumahan yang terletak di Jalan Adi Sucipto (004'04,1'S 109²2'135,0”'E).

\section{TINJAUAN PUSTAKA}

Kartasapoetra (1987) mengatakan Industri adalah kegiatan ekonomi yang mengolah bahanbahan mentah, bahan baku, barang setengah jadi atau barang jadi menjadi barang yang bernilai tinggi. Menurut Undang-Undang Republik Indonesia No. 5 Tahun 1984 tentang perindustrian, industri adalah kegiatan ekonomi yang mengolah bahan mentah, bahan baku, barang setengah jadi, dan atau barang jadi menjadi barang dengan nilai tinggi untuk penggunaannya, termasuk kegiatan rancang bangun dan perekayasaan industri.

Menurut Nohong (2010), Limbah tahu berasal dari buangan atau sisa pengolahan kedelai menjadi tahu yang terbuang karena tidak terbentuk dengan baik menjadi tahu sehingga tidak dapat dikonsumsi. Limbah tahu terdiri atas dua jenis yaitu limbah cair dan limbah padat. Limbah cair merupakan bagian terbesar dan berpotensinya mencemari lingkungan. Limbah ini terjadi karena adanya sisa air tahu yang tidak menggumpal, potongan tahu yang hancur karena proses penggumpalan yang tidak sempurna serta cairan keruh kekuningan yang dapat menimbulkan bau tidak sedap bila dibiarkan.

Menurut Bahri (2006), menyatakan bahwa limbah cair yang dihasilkan industri banyak mengandung senyawa organik, dan sedikit senyawa anorganik. Senyawa organik apabila berada pada konsentrasi tinggi akan menimbulkan pencemaran pada lingkungan perairan. Air limbah dari industri tahu memerlukan pengolahan sebelum dibuang ke badan air. Kandungan 
fosfor, nitrogen dan sulfur serta unsur hara lainnya dengan konsentrasi tinggi di dalam air akan mempercepat pertumbuhan tumbuhan air.

Proses pengolahan limbah secara biologis lebih efektif, efisien, ekonomis dan ramah lingkungan. Proses pengolahan limbah secara biologis dapat berlangsung secara anaerob dan aerob. Proses anaerob yaitu suatu proses penguraian bahan organik dilakukan dengan bakteri yang dalam aktivitasnya tidak memerlukan oksigen $\left(\mathrm{O}_{2}\right)$, sedangkan proses aerob yaitu suatu proses dilakukan dengan bakteri yang dalam aktivitasnya memerlukan oksigen (Baker, 2011).

Usaha minimasi produksi bersih didefinisikan sebagai strategi pengelolaan lingkungan yang bersifat preventif, terpadu, dan diterapkan secara terus-menerus pada setiap kegiatan mulai dari hulu ke hilir yang terkait dengan proses produksi (KLH, 2003). Produksi bersih memiliki tujuan untuk meningkatkan produktivitas dengan memberikan tingkat efisiensi yang lebih baik pada penggunaan bahan mentah, energi dan air, mendorong performansi lingkungan yang lebih baik melalui pengurangan sumber-sumber pembangkit limbah dari emisi serta mereduksi dampak produk terhadap lingkungan dari siklus hidup produk dengan rancangan yang ramah lingkungan, namun efektif dari segi biaya (UNIDO, 2002).

\section{METODE PENELITIAN}

Tempat industri tahu terletak di Jalan Adi Sucipto gang sepakat, terletak di pinggir Sungai Kapuas $\left(0^{\circ} 04^{\prime} 04,1\right.$ 'S $\left.; 109^{\circ} 22^{\prime} 135^{\prime \prime} \mathrm{E}\right)$. Metode yang digunakan pada penelitian ini adalah studi literatur, analisis deskriptif, observasi langsung dan survey lapangan. Studi literatur adalah cara yang dipakai untuk menghimpun data-data atau sumber-sumber yang berhubungan dengan topik yang diangkat dalam suatu penelitian. Analisis deskriptif dilakukan dengan meneliti tahapan proses produksi dengan membuat diagram alir proses yang dimana dilakukan dengan melihat secara langsung produksi tahu di industri tahu itu sendiri. Studi literatur didapatkan dari berbagai sumber seperti jurnal, buku dan dokumentasi. Alat yang digunakan dalam penelitian ini yaitu, alat tulis. Sedangkan bahan yang dipantau selama penelitian proses pembuatan tahu adalah kedelai, air, penggumpal, limbah cair, limbah padat dan tahu. Berikut merupakan diagram alir tahap penelitian: 


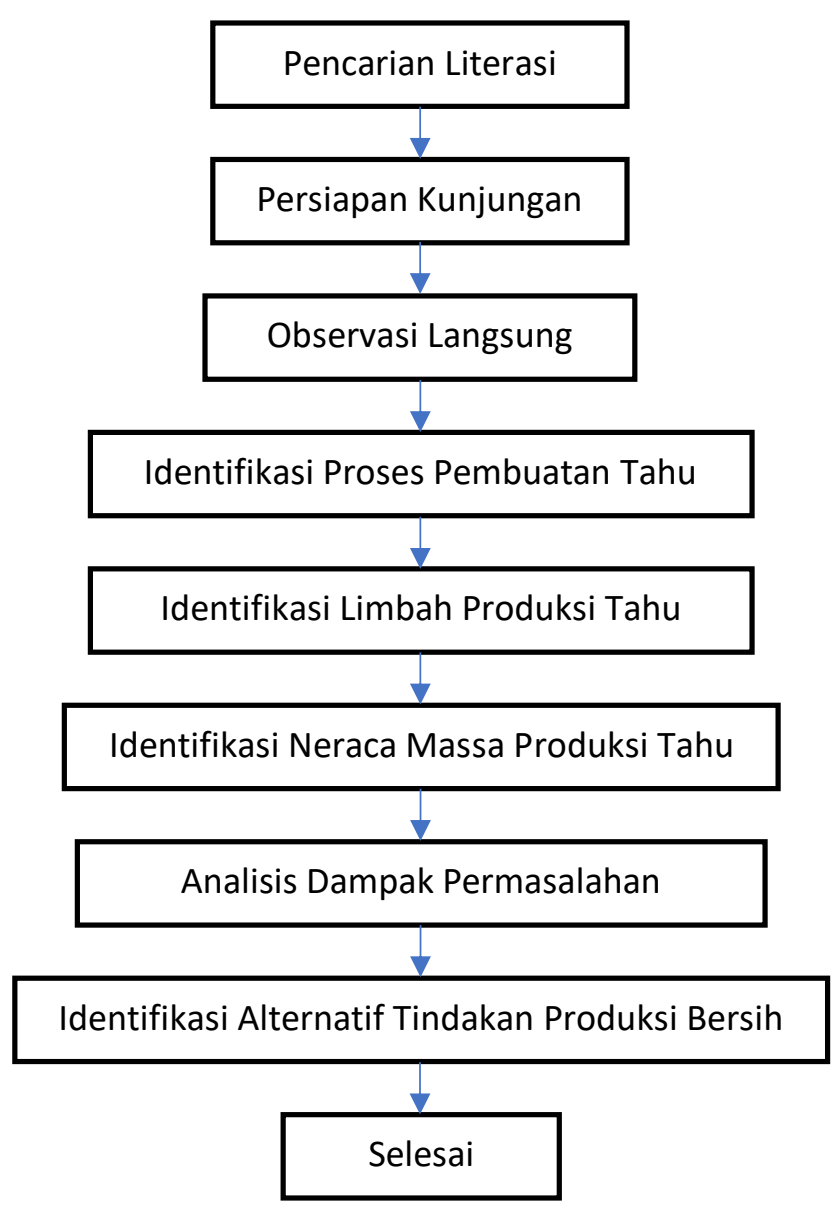

Gambar 1. Diagram Alir Tahap Penelitian

Identifikasi yang dilakukan selanjutnya adalah identifikasi kondisi limbah hasil produksi yang berupa warna, bau, $\mathrm{pH}$, dan suhu pada limbah cair produksi tahu. Hasil akan dibandingkan dengan baku mutu limbah cair yang ada. Selanjutnya, mengidentifikasi neraca massa produksi tahu dimana produksi ini dilakukan untuk mengetahui banyaknya input dan output yang dihasilkan pada proses produksi tahu.

\section{HASIL DAN PEMBAHASAN}

\section{Kondisi Umum Industri}

Industri ini buka setiap hari pada pukul 13.00-18.00 WIB. Setiap hari industri tahu memproduksi $150 \mathrm{~kg}$ kedelai dalam 2 kali produksi. Setiap produksi industri ini dapat menghasilkan 1500 potong tahu.

\section{Proses Produksi Tahu}

Proses perendaman kedelai memerlukan waktu selama 4 jam. Proses ini dilakukan dalam drum plastik ukuran $100 \mathrm{~kg}$. Perbandingan kedelai : air adalah $3: 1$. Kedelai yang digunakan sebanyak $75 \mathrm{~kg}$ dan air $25 \mathrm{~L}$.

Proses penggilingan kedelai dilakukan menggunakan alat penggiling dengan air yang dialirkan melalui selang ukuran $3 / 4$ yang diambil dari hasil filtrasi air sungai. Proses ini menghasilkan limbah padat berupa ampas kedelai dan bubur kedelai. Setiap $75 \mathrm{~kg}$ kedelai kering akan menghasilkan bubur kedelai sebanyak $175 \mathrm{~L}$ dan menghasilkan ampas kedelai yang telah digiling sebanyak 1 karung ukuran $50 \mathrm{~kg}$. 
Proses pemasakan bubur kedelai dilakukan menggunakan besi pemanas yang dicelupkan ke dalam drum bubur kedelai. Pemasakan dilakukan hingga bubur kedelai mendidih. Setelah mendidih, bubur kedelai akan melalui tahapan penyaringan.

Proses penyaringan dilakukan menggunakan kain sifon yang dimana ampas kedelai yang masih tercampur kedalam bubur kedelai akan menghasilkan filtrat dan ampas tahu. Setelah itu, hasil penyaringan ditambah dengan asam cuka untuk mengendapkan dan menggumpalkan protein sehingga dapat memisahkan whey dengan gumpalan. Proses ini menghasilkan sebanyak $150 \mathrm{~L}$ gumpalan protein.

Proses pencetakan gumpalan protein sebanyak $150 \mathrm{~L}$ kemudian dibungkus dengan kain dan dipadatkan. Setelah padat, bungkus kain dibuka kemudian ditiriskan untuk selanjutnya dilakukan pemotongan. Sekali produksi menghasilkan 1500 potong. Setelah dipotong, dilakukan proses perendaman dengan air panas yang telah di tambahkan bumbu.

\section{Output/Limbah yang dihasilkan}

1. Proses Perendaman Kedelai Limbah cair dari sisa perendaman kedelai

2. Proses penggilingan Limbah padat yang digunakan untuk pakan ternak.

3. Proses Penyaringan limbah padat

4. Proses Pencetakan limbah cair

5. Proses Perendaman Tahu limbah cair

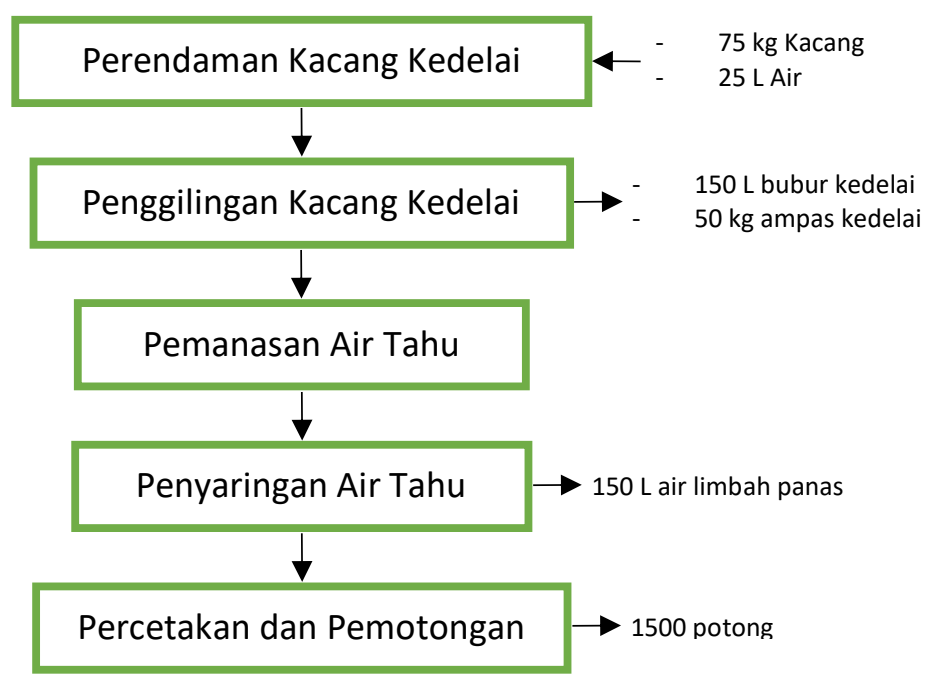

Gambar 2. Diagram Alir Proses Produksi Tahu

\section{Pemanfaatan Limbah Cair Industri Tahu}

Limbah cair tahu dapat dijadikan alternatif baru yang digunakan sebagai pupuk sebab di dalam limbah cair tahu tersebut memiliki ketersediaan nutrisi yang dibutuhkan oleh tanaman (Handayani, 2005). Kandungan hara limbah cair industri tahu sebelum dan setelah dibuat pupuk cair memenuhi standar pupuk cair Baku mutu pupuk cair yang dipersyaratkan oleh 
Permentan Nomor: 28//SR.130/B/2009 sehingga dapat dimanfaatkan untuk pupuk cair organik yang dapat digunakan untuk pemupukan tanaman kangkung darat. Dari pemaparan sebelumnya, untuk mengatasi limbah cair tahu yang semakin meningkat, maka limbah cair tersebut dapat diolah sebagai pupuk cair organik. (Aliyenah, 2015).

Limbah cair tahu dapat dijadikan alternatif baru yang digunakan sebagai pupuk sebab di dalam limbah cair tahu tersebut memiliki ketersediaan nutrisi yang dibutuhkan oleh tanaman. Hasil penelitian menunjukkan bahwa pemberian limbah cair tahu berpengaruh terhadap pertumbuhan vegetatif tanaman kedelai yaitu tinggi tanaman dan jumlah daun (Ernawati dalam Anggit, 2010).

\section{Alat dan Bahan}

Alat yang digunakan dalam penelitian ini adalah ember cat, botol plastik, selang, dan tongkat kayu. Sedangkan bahan yang digunakan dalam penelitian ini adalah, 5 liter/5000 ml limbah cair tahu, 33 gr gula merah, dan $33 \mathrm{ml}$ cairan aktivator (EM4)

\section{Prosedur Pembuatan Pupuk Organik}

1. Limbah cair dimasukkan ke dalam ember sebanyak 5 liter atau $5000 \mathrm{ml}$, larutan gula merah sebanyak $167 \mathrm{ml}$ dan larutan aktivator EM4 sebanyak $33 \mathrm{ml}$.

2. Diaduk dengan rata menggunakan tongkat kayu.

3. Ember ditutup rapat sehingga udara tidak bisa masuk.

4. Dibuat saluran pengeluaran gas yang ujung pipanya dimasukkan kedalam botol plastik yang berisi air dan diamkan selama 15 hari.

5. Pupuk cair disaring hingga larutan bersih. 


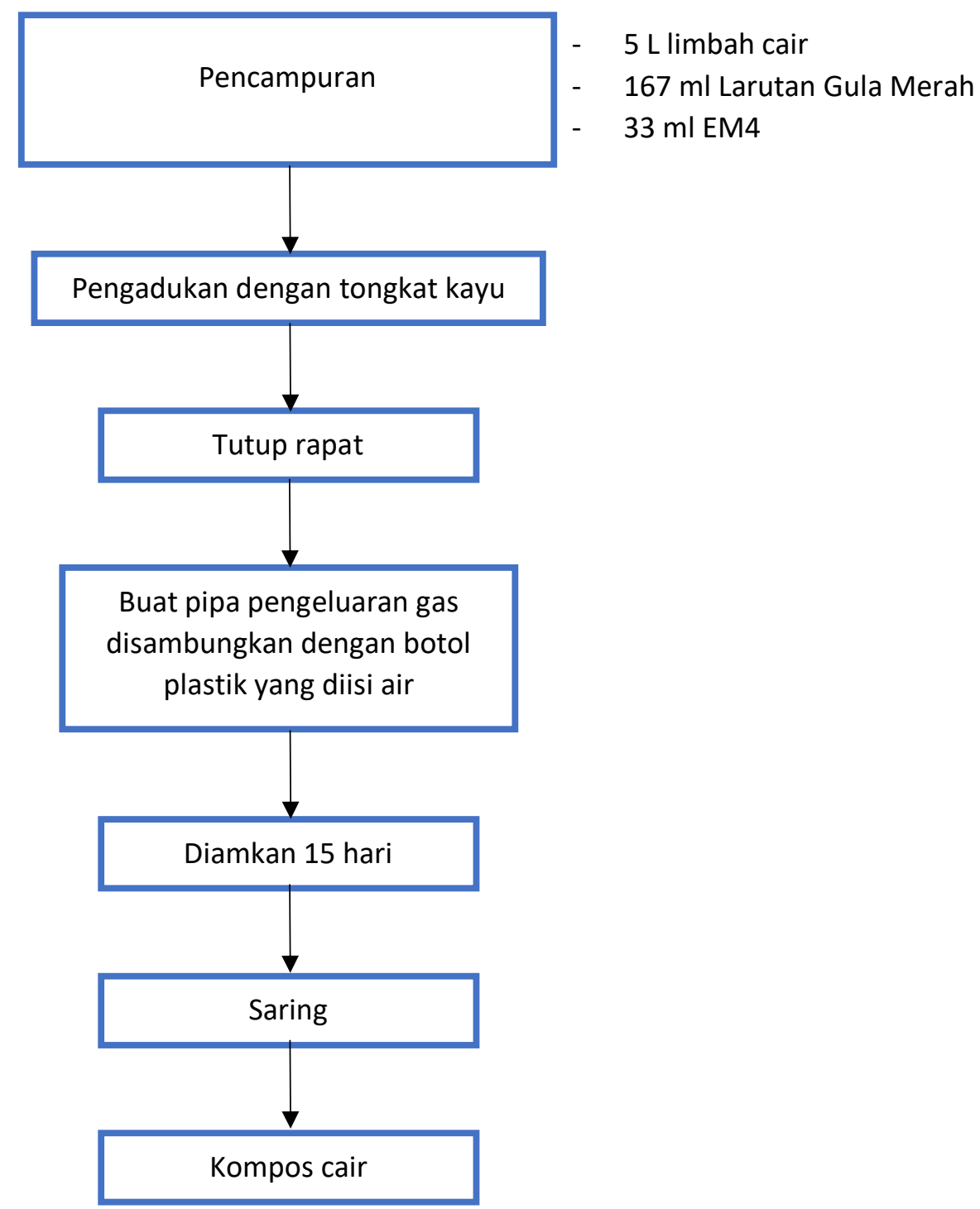

Gambar 3. Diagram Alir Produksi Bersih

\section{PENUTUP}

\section{Kesimpulan}

Kesimpulan yang dapat diambil dari kunjungan ke pabrik industri tahu rumahan di Jalan Adi Sucipto Gang Sepakat adalah :

1. Pabrik industri tahu menghasilkan limbah cair yang langsung dibuang ke sungai dan limbah padat yang dijadikan pakan ternak

2. Produksi bersih yang dapat ditawarkan untuk limbah cair adalah dengan membuat pupuk organik dari limbah tersebut.

\section{Saran}

Saran yang dapat diberikan kepada industri tahu rumahan ini adalah menerapkan penggunaan produksi bersih terhadap limbah yang dihasilkan agar dapat meminimalisir pencemaran.

\section{DAFTAR PUSTAKA}

Ananda, Eka Resky, dkk. 2018. Pembuatan Alat Pengolah Limbah Cair dengan Metode Elektrokoagulasi untuk Industri Tahu Kota Samarinda. Jurusan Teknik Kimia, Politeknik Negeri Samarinda. Jurnal Teknologi Terpadu Vol. 6 No. 1. ISSN 2338 - 6649. 
Azhari, Muhammad. 2016. Pengolahan Limbah Tahu dan Tempe dengan Metode Teknologi Tepat Guna Saringan Pasir sebagai Kajian Mata Kuliah Pengetahuan Lingkungan. Program Studi Teknik Lingkungan Universitas Muhammadiyah Palangkaraya. Media Ilmiah Teknik Lingkungan Volume 1 Nomor 2 Hal. 1-8

Bahri, Djamarah Syaful. 2006. Strategi Belajar Mengajar. Jakarta : PT. RENIKA CIPTA

Baker, H. Kent. 2011. Capital Structure and Corporate Financing Decisions. Canada: John Wiley \& Sons, Inc

Djayanti, Silvy. 2015. Kajian Penerapan Produksi Bersih di Industri Tahu di Desa Jimbaran, Bandungan, Jawa Tengah. Balai Besar Teknologi Pencegahan Pencemaran Industri. Jurnal Riset Teknologi Pencemaran Industri Vol.6, No. 2: 75 - 80.

Indrasti, N.S. dan Fauzi, A.M. 2009. Produksi Bersih. IPB Press. Bogor.

Kartasapoetra. 1987. Teknologi Konservasi Tanah dan Air. Jakarta: Rineka. Cipta

Keputusan Menteri Lingkungan Hidup Nomor 112 Tahun 2003 Tentang Baku Mutu Air Limbah Domestik.

Kurniawati, Dwi Agustina, dkk. 2020. Peningkatan Eko-Efisiensi dan Produktivitas Industri Kecil dan Menengah (IKM) Tahu di Desa Dukuh Kecamatan Mantrijeron Yogyakarta. Program Studi Teknik Industri, Fakultas Sains dan Teknologi. Universitas Islam Negeri Sunan Kalijaga. Dinamika Journal, Vol. 2 No. 2 : 16 - 24. ISSN : 2686-2158

Kusumadewi, N \& Hartati, R. 2003. Absorbsi Pakan Pada Saluran Pencernaan Teripang Hitam (Holothuria atra). Journal Perikanan dan Ilmu Kelautan 3 (XII) : 87 - 95

Nohong. 2010. Pemanfaatan Limbah Tahu Sebagai Bahan Penyerap Logam Krom, Kadmiun dan Besi Dalam Air Lindi TPA. Jurnal Pembelajaran Sains, Vol. 6, No. 2: 257-269.

Purwanto. 2009. Evaluasi Hasil Belajar. Surakarta: Pustaka Belajar.

Romli, Muhammad dan Suprihatin. 2009. Beban Pencemaran Limbah Cair Industri Tahu dan Analisis Alternatif Strategi Pengelolaannya. Jurnal Purifikasi, Departemen Teknologi Industri Pertanian, Fakultas Teknologi Pertanian IPB. Vol. 10, No. 2: 141 - 154

SAENAB, SITTI, dkk. 2018. Pemanfaatan Limbah Cair Industri Tahu Sebagai Pupuk Organik Cair (POC) Guna Mendukung Program Lorong Garden (Longgar) Kota Makassar. Jurusan Biologi, Fakultas Sains dan Teknologi, UIN Alauddin Makassar. ISBN: 978602-72245-3-7.

Samsudin, Winda, dkk. 2018. Pengolahan Limbah Cair Industri Tahu Menjadi Pupuk Organik Cair dengan Penambahan Efektive Mikroorganisme-4 (EM-4). Jurnal Nasional Ilmu Kesehatan (JNIK) LP2M Unhas, Vol 1, 2. ISSN: 2621-6507.

Sudarman, dkk. 2015. Penerapan Ketel Uap (Steam Boiler) pada Industri Pengolahan Tahu untuk Meningkatkan Efisiensi dan Kualitas Produk. Jurusan Teknik Mesin Fakultas Teknik Universitas Negeri Semarang. Vol. 13 No.1.

Sungkowo, Toto Heri, dkk. 2015. Pengolahan Limbah Cair Industri Tahu Menggunakan Tanaman Typha Latifolia dan Eceng Gondok dengan Metode Fitoremediasi. JOM FTEKNIK Volume 2 No. 2

United Nation Industrial Development Organization (UNIDO). 2002. Manual on the Development of Cleaner Production Policies - Approaches and Instruments. UNIDO CP Programme. Vienna.

Zulmi, Akhmad, dkk. 2018. Analisis Kelayakan Penerapan Produksi Bersih pada Industri Tahu UD. Sugih Waras Desa Atu-atu Kecamatan Pelaihari. Jurusan Teknologi Industri Pertanian, Politeknik Negeri Tanah Laut Jurnal Teknologi Agro Industri Vol. 5 No. 1 ISSN 2598-5884 ISSN 2407-4624 